\begin{tabular}{c|c|c}
\hline JURNAL PENELITIAN KESMASY & VOL. 1 NO. 2 & $\begin{array}{c}\text { EDITION: NOVEMBER 2018 - } \\
\text { APRIL } 2019\end{array}$ \\
\hline \multirow{2}{*}{ RECEIVED: 24 FEBRUARI 2019} & http://ejournal.delihusada.ac.id/index.php/JPKSY & ACCEPTED: 28 APRIL 2019 \\
\cline { 2 - 3 } & REVISED: 21 MARET 2019 & ACP \\
\hline
\end{tabular}

\title{
HUBUNGAN PENINGKATAN KADAR LDL KOLESTEROL PADA PASIEN STROKE ISKEMIK DI RUMAH SAKIT UMUM HAJI MEDAN
}

\author{
Zaim Anshari \\ Universitas Islam Sumatera Utara, Jl. STM No 77 Medan \\ Email: zaim.ashari@fk.uisu.ac.id
}

\begin{abstract}
Introduction: The causes of ischemic stroke by the high level of Idl cholesterol is still uncertain or can not be confirmed yet. The researches regarding the correlation of the high level of Idl cholestrol on the ischemic stroke patients only in small numbers with inconsistent result. Purpose: to know the correlation of high level of idl cholestrol on ischemic stroke patients. Method: this research is an analytic research by using restrospective study method on ischemic stroke patients whom hospitalized in Haji Medan General Hospital period January to Maret 2019. The datas were taken from patient medical records. Those datas will be analyzed by using chi square test. Result: there were 40 subjects whom are in ages of 61-70 years old. There was no correlation of high level of Idl cholestrol on ischemic stroke patients $(p=0.943)$ which means $(p>0.05) \mathrm{H} \circ$ is unaccepted. Discussion: there is no correlation of high level of Idl cholestrol on ischenic stroke patients
\end{abstract}

Key Words : LDL cholestrol, ischemic stroke

\section{PENDAHULUAN}

Stroke didefinisikan sebagai sebuah syndrome yang memiliki karakteristik tanda dan gejala neurologis klinis fokal dan atau global yang berkembang dengan cepat, adanya gangguan fungsi serebral, dengan gejala yang berlangsung lebih dari 24 jam atau menimbulkan kematian tanpa terdapat penyebab selain yang beasal dari vascular (Tanto, 2014).

Di Amerika diperkirakan setiap tahunnya masih terjadi sekitar 500.000 pasien stroke baru dan sekitar 150.000 yang meninggal karena stroke. Insiden stroke Hemoragik antara 15\% - 30\% dan Stroke Iskemik antara 70\% - 85\%. Stroke Iskemik disebabkan antara lain oleh thrombosis otak (penebalan dinding arteri) akibat peningkatan kadar LDL kolesterol $60 \%$, emboli $5 \%$ (sumbatan mendadak), dan lainlain 35\%. Meski kasusnya lebih sedikit dibandingkan Stroke Iskemik, namun stroke hemoragik sering mengakibatkan kematian. Umumnya sekitar $50 \%$ kasus stroke hemoragik akan berujung kematian, sedangkan pada stroke iskemik hanya 20\% yang berakibat kematian (Junaidi, 2011).

Menurut hasil riskesdas 2007, stroke merupkan salah satu penyakit tidak menular utama penyebab kematian di Indonesia selain hipertensi, penyakit jantung iskemik dan penyakit jantung lainnya dengan angka kejadian stroke di Indonesia adalah sebesar 8,3 per 1000 penduduk (Agusti dkk, 2014).

Prevalensi stroke di Indonesia berdasarkan diagnosis tenaga kesehatan sebesar 7 per mil dan terdiagnosis tenaga kesehatan atau gejala sebesar 12,1 per mil. Prevalensi penyakit stroke pada kelompok yang di diagnosis nakes atau gejala meningkat seiring dengan bertambahnya umur, tertinggi pada umur lebih dari 75 tahun (43,1\%). Prevalensi stroke yang terdiagnosis nakes maupun berdasarkan diagnosis atau gejala sama tinggi pada lakilaki dan perempuan (Riskesdas, 2013).

Dari data pasien stroke di RSUP Prof. Dr. R. D. Kandou Manado berdasarkan kadar kolesterol LDL menunjukkan bahwa pada pasien stroke iskemik ada 42 pasien $(19,81 \%)$ memiliki kadar kolesterol LDL yang optimal, 45 pasien $(21,23 \%)$ mendekati optimal, 24 pasien $(11,32 \%)$ yang diinginkan, 13 pasien $(6,13 \%)$ tinggi, dan 12 pasien (5,66\%) sangat tinggi. Untuk stroke hemoragik, ada 14 pasien $(6,60 \%)$ memiliki kadar kolesterol LDL yang optimal, 26 pasien (12,26\%) mendekati optimal, 20 pasien $(9,43 \%)$ yang diinginkan, 12 pasien $(5,66 \%)$ tinggi, dan 4 pasien $(1,9 \%)$ 


\begin{tabular}{c|c|c}
\hline \multirow{2}{*}{ JURNAL PENELITIAN KESMASY } & VOL. 1 NO. 2 & $\begin{array}{c}\text { EDITION: NOVEMBER 2018 - } \\
\text { APRIL 2019 }\end{array}$ \\
\hline \multirow{2}{*}{ RECEIVED: 24 FEBRUARI 2019 } & http://ejournal.delihusada.ac.id/index.php/JPKSY & ACCEPTED: 28 APRIL 2019 \\
\cline { 2 - 3 } & REVISED: 21 MARET 2019 & AC
\end{tabular}

sangat tinggi. LDL kolesterol memiliki kecenderungan melekat di dinding pembuluh darah sehingga dapat menyempitkan pembuluh darah, terutama pembuluh darah kecil yang menyuplai makanan ke jantung dan otak. Kadar LDL kolesterol berlebihan akan mengendap pada dinding pembuluh darah arteri dan membentuk plak serta menimbulkan dan menyebabkan penumpukan lemak yang memicu aterosklerosis. Plak terlepas dan menyebabkan stroke (Laulo,dkk,2016).

Dari seluruh subjek yang diamati dalam 30 hari di RSUP H. Adam Malik Medan, periode Agustus hingga November, didapati 12 $(23,5 \%)$ orang meninggal. Dari jumlah tersebut, $10(83,3 \%)$ orang berasal Dari grup stroke iskemik, dan $2(16,7 \%)$ orang dari stroke hemoragik. Angka kematian lebih besar dijumpai pada subjek dengan kadar LDL $\leq 130$ $\mathrm{mg} / \mathrm{dL}(33,3 \%)$ dibandingkan dengan subjek dengan kadar LDL $>130 \mathrm{mg} / \mathrm{dL} \quad(5,6 \%)$, $\mathrm{p}=0,037$, dengan peningkatan Rasio Odds sebesar 6 kali (IK95\%, 0,841-42,8) (Effrina dkk, 2015).

Dari hasil penelitian ini didapatkan bahwa mayoritas pasien stroke iskemik lebih banyak dibandingkan dengan pasien stroke hemoragik. Dari 50 pasien stroke rawat inap didapatkan jumlah pasien stroke iskemik sebanyak 42 pasien (84\%), sedangkan stroke hemoragik sebanyak 8 pasien (16\%) jumlah pasien stroke jenis iskemik atau nonhemoragik lebih banyak dibandingkan stroke hemoragik. Stroke Iskemik disebabkan karena adanya endapan lemak dan kolesterol. Pembentukan plak yang menyebabkan stroke iskemik berada dalam dinding pembuluh darah arteri di leher dan kepala (Zai, 2015).

Stroke adalah penyakit pada otak berupa gangguan fungsi syaraf lokal dan/atau global, munculnya mendadak, progresif, dan cepat. Gangguan fungsi syaraf pada stroke disebabkan oleh gangguan peredaran darah otak non traumatik. Gangguan syaraf tersebut menimbulkan gejala antara lain: kelumpuhan wajah atau anggota badan, bicara tidak lancar, bicara tidak jelas (pelo), mungkin perubahan kesadaran, gangguan penglihatan, dan lain-lain. Didefinisikan sebagai stroke jika pernah didiagnosis menderita penyakit stroke oleh tenaga kesehatan (dokter/perawat/bidan) atau belum pernah didiagnosis menderita penyakit stroke oleh nakes tetapi pernah mengalami secara mendadak keluhan kelumpuhan pada satu sisi tubuh atau kelumpuhan pada satu sisi tubuh yang disertai kesemutan atau baal satu sisi tubuh atau mulut menjadi mencong tanpa kelumpuhan otot mata atau bicara pelo atau sulit bicara/komunikasi dan atau tidak mengerti pembicaraan (Riskesdas 2013).

Stroke iskemik atau bisa disebut juga non hemoragik di defenisikan secara patofisiologi sebagai kematian jaringan otak karena pasokan darah yang tidak adekuat. Definisi klinis stroke iskemik ialah deficit neuologis fokal yang timbul akut dan belangsung lebih lama dari 24 jam dan tidak disebabkan oleh perdarahan.

Stroke hemoragik disebabkan oleh ruptur arteri. Baik intraserebral maupun subaraknoid. Perdarahan intraserebral merupakan penyebab tersering, dimana dinding pembuluh darah kecil yang sudah rusak akibat hipertensi kronik. Hematoma yang tebentuk akan menyebabkan peningkatan tekanan intracranial (TIK). Perdarahan subarachnoid disebabkan oleh pecahnya aneurisma atau malformasi arteri vena yang perdarahannya masuk kerongga subarachnoid, sehingga menyebabkan cairan serebospinal (CSS) terisi oleh darah. Darah di dalam CSS akan menyebabkan vasospasme sehingga menimbulkan gejala sakit kepala hebat yang mendadak (Tanto, 2014).

Vaskuler; arteoskleosis, displasi fibromuskuler, inflamasi (giant cell ateritis, SLE, poliarteritis nodusa, angiitis granuloma, arteritis sifilitika, AIDS), diseksi arteri, penyalahgunaan obat, sindrom moyamoya, thrombosis sinus, atau vena. Kelainan Jantung: thrombus mural, aritmia jantung, endokarditis infeksiosa, dan noninfeksiosa, penyakit jantung rematik, penggunaan katup jantung postetik, miksoma atrial, dan fibrilasi atrium. Kelainan Darah: trombositosis, polisitemia, anemia sel sabit, hiperkoagulasi, dan hiperviskositas darah.

Pemeriksaan penunjang stroke yaitu: Elektrokardigrafi, Laboatoium (kimia darah, fungsi ginjal, hematologi, hemostatis, gula darah, urinalisis, analisis gas darah, dan elektolit), Foto Thoraks : untuk melihat adanya gambaran kardiomegali sebagai penanda adanya hipertensi untuk factor resiko stroke, CT scan/MRI : gambaran hipodens/hipointens / hiperintens pada stroke hemoragik pada T1W1， Transcranial Doppler (TCD) dan 


\begin{tabular}{|c|c|c}
\hline JURNAL PENELITIAN KESMASY & VOL. 1 NO. 2 & $\begin{array}{c}\text { EDITION: NOVEMBER 2018 - } \\
\text { APRIL 2019 }\end{array}$ \\
\hline & http://ejournal.delihusada.ac.id/index.php/JPKSY & \\
\cline { 2 - 3 } RECEIVED: 24 FEBRUARI 2019 & REVISED: 21 MARET 2019 & ACCEPTED: 28 APRIL 2019 \\
\hline
\end{tabular}

Doppler karotis, antara lain untuk melihat adanya penymbatan dinding pembuluh darah sebagai risiko stroke, Analisa cairan serebrospinal jika diperlukan (Tanto, 2014).

Kolesterol mempunyai tiga fungsi penting yaitu: membantu membuat lapisan luar atau dinding dinding sel, menghasilkan asam empedu guna membantu mengurai makanan, serta membantu tubuh membuat vitamin D dan hormone. Kolesterol merupakan zat gizi atau komponen lemak kompleks yang di butuhkan oleh tubuh sebagai salah satu sumber energy yang memberikan kalori paling tinggi dan juga merupakan bahan dasar pembentukan hormone steroid. Sebagai lemak, koleterol melayang-layang, seperti minyak di dalam air, untuk dapat melayang, di butuhkan protein yang membungkusnya yang sering disebut lipoprotein. Lipoprotein adalah kompleks makromolekul yang membawa lemak plasma hidrofobik, yaitu kolesterol dan trigliserida dalam darah. Lipoprotein akan membawa kolesterol ke seluruh sel tubuh, setelah lemak berikatan dengan apoprotein, akan membentuk lipoprotein, sehingga lemak dapat larut di dalam darah.

Low density lipoprotein (LDL): LDL disebut juga kolesterol buruk, dapat menyebabkan penumpukan plak di dinding arteri. Semakin banyak LDL adadalam darah, semakin besar risiko penyakit jantung. High density lipoproteins (HDL): HDL disebut juga kolesterol baik, membantu tubuh menyingkirkan kolesterol jahat dalam darah. Semakin tinggi tingkat kolesterol HDL, semakin baik. Bila kadar HDL yang rendah, risiko penyakit jantung meningkat. Very low density lipoproteins (VLDL): VLDL mirip dengan kolesterol LDL di dalamnya berisi sebagian besar lemak dan tidak banyak protein.

\section{METODE PENELITIAN}

Penelitian ini dilaksanakan di Rumah Sakit Umum Haji Medan, jalan Rumah Sakit Haji, Medan Estate dan waktu penelitian dilaksanakan pada bulan Maret 2019 sampai selesai. Populasi adalah keseluruhan dari subyek penelitian. Yang akan digunakan dalam penelitian ini berasal dari data sekunder yaitu rekam medik pasien yang menderita penyakit stroke iskemik dan melakukan pemeriksaan kadar Idl kolesterol dari tanggal 1 januari sampai dengan 30 Maret 2019 di rumah sakit umum haji medan, berdasarkan dari data bagian rekam medik di rumah sakit haji medan 2016, pasien yang mengalami penyakit stroke iskemik dan menjalankan pemeriksaan kadar Idl kolesterol bejumlah 68 orang.

Berdasarkan pemilihan dengan kriteria inklusi populasi yang memenuhi syarat sebanyak 68 orang. Untuk perhitungan jumlahsampel dalam penelitian inimenggunakan teknik purposive random sampling dimana seluruh populasi pasien yang berkunjung ke poli saraf di Rumah Sakit Umum Haji Medan pada bulan Januari sampai Maret 2019 yang memenuhi syaratdiambil sebagai sampel dalam penelitian. Sehingga sampel dalam penelitian iniberjumlah sebanyak 40 orang. Intrumen penelitian adalah alat-alat yang digunakan pada waktu penelitian untuk mengumpulkan data (Arikunto, 2014). Intrumen yang digunakan dalam penelitian ini adalah hasil rekam medis data lembar checklist.

\section{HASIL PENELITIAN}

\section{Analisis Univariat}

Tabel 1. Distribusi frekuensi pasien stroke berdasarkan usia.

\begin{tabular}{ccc}
\hline Umur & Frekuensi (F) & Persentase (\%) \\
\hline $35-41$ & 3 & 7.5 \\
$42-48$ & 0 & 0 \\
$49-55$ & 4 & 10.0 \\
$56-62$ & 14 & 35.0 \\
$63-69$ & 11 & 27.5 \\
$70-76$ & 7 & 17.5 \\
$77-83$ & 1 & 2.5 \\
Total & 40 & 100.0 \\
\hline
\end{tabular}

Pada tabel 4.1 di dapatkan hasil yaitu Distribusi pasien stroke berdasarkan usia yang terbanyak kelompok usia 56-62 dengan jumlah 14 pasien (35,0\%),medium usia 63-69 dengan jumlah 11 pasien (27,5\%), usia 70-76 dengan jumlah 7 pasien $(17,5 \%)$, usia 49-55 dengan jumlah 4 pasien $(10,0 \%)$, usia 35-41 dengan jumlah 3 pasien (7,5\%) usia paling sedikit 7783 dengan jumlah 1 pasien $(2,5 \%)$ dan tidak ada pasien yang menderita stroke pada usia 42-48. 


\begin{tabular}{|c|c|c|}
\hline JURNAL PENELITIAN KESMASY & VOL. 1 NO. 2 & $\begin{array}{c}\text { EDITION: NOVEMBER } 2018- \\
\text { APRIL } 2019\end{array}$ \\
\hline & http://ejournal.delihusada.ac.id/index.php/JPKSY & \\
\hline RECEIVED: 24 FEBRUARI 2019 & REVISED: 21 MARET 2019 & ACCEPTED: 28 APRIL 2019 \\
\hline
\end{tabular}

Tabel 2. Distribusi frekuensi stroke berdasarkan jenis kelamin

\begin{tabular}{lcc}
\hline Jenis kelamin & $\begin{array}{c}\text { Frekuensi } \\
(\mathrm{F})\end{array}$ & $\begin{array}{c}\text { Persentase } \\
(\%)\end{array}$ \\
\hline Perempuan & 25 & 62,5 \\
Laki-laki & 15 & 37,5 \\
$\quad$ Total & 40 & 100 \\
\hline
\end{tabular}

Distribusi pasien stroke berdasarkan jenis kelamin terbanyak di derita oleh perempuan yaitu 25 orang pasien $(62,5 \%)$, paling sedikit pasien laki-laki sebanyak 15 orang pasien $(37,5 \%)$.

Tabel 3 Distribusi Frekuensi Kadar LDL Kolesterol pada Pasien Stroke

\begin{tabular}{lcc}
\hline Kadar Idl $(\mathrm{mg} / \mathrm{dl})$ & $\begin{array}{c}\text { Frek } \\
(\mathrm{F})\end{array}$ & $\begin{array}{c}\text { Persentasi } \\
(\%)\end{array}$ \\
\hline Normal $(<130)$ & 21 & 52,5 \\
Sedang $(130-159)$ & 7 & 17,5 \\
Berat $(>160)$ & 12 & 30 \\
$\quad$ Total & 40 & 100 \\
\hline
\end{tabular}

Berdasakan tabel 4.3 didapatkan hasil bahwa pasien yang menderita stroke dengan kadar Idl normal $(<130 \mathrm{mg} / \mathrm{dl})$ terbanyak yaitu 21 orang $(52,5 \%)$, kadar Idl sedang $(130-159 \mathrm{mg} / \mathrm{dl})$ sebanyak 7 orang $(17,5 \%)$, sedangkan kadar Idl yang tinggi $(>160 \mathrm{mg} / \mathrm{dl})$ sebanyak 12 orang (30\%).

Tabel 4 distribusi frekuensi berdasarkan jenis stroke

\begin{tabular}{ccc}
\hline Jenis stroke & $\begin{array}{c}\text { Frekuensi } \\
(\mathrm{F})\end{array}$ & $\begin{array}{c}\text { Persentasi } \\
(\%)\end{array}$ \\
\hline Stroke iskemik & 18 & 45 \\
Stroke hemoragik & 22 & 55 \\
Total & 40 & 100 \\
\hline
\end{tabular}

Berdasarkan tabel 4.4 didapatkan hasil bahwa pasien yang terbanyak mengalami stroke hemoragik 20 orang pasien (55\%), yang paling sedikit yaitu stroke iskemik ada 18 orang pasien (45\%).

Tabel 5 Hubungan kadar Idl dengan kejadian stroke iskemik dan stroke hemoragik

\begin{tabular}{lcccc}
\hline Tipe & \multicolumn{3}{c}{ Kadar LDL } & \multirow{2}{*}{$p$} \\
\cline { 2 - 4 } stroke & Normal & Sedang & Berat & \\
\hline Stroke & 10 & 2 & 6 & 0,943 \\
Iskemik & $(47,6 \%)$ & $(28,6 \%)$ & $(50 \%)$ & \\
& & & & \\
Stroke & 11 & 5 & 6 & \\
Hemoragik & $(52,4 \%)$ & $(71,4 \%)$ & $(50 \%)$ & \\
\hline
\end{tabular}

Kadar LDL kolesterol dikategorikan menjadi 3 kelompok yaitu, normal $(<130 \mathrm{mg} / \mathrm{dl})$, sedang $(130-156 \mathrm{mg} / \mathrm{dl})$, dan tinggi (>160 mg/dl). Tidak ditemukan tidak adanya hubungan pada subyek stroke iskemik maupun stroke hemoragik ( $p=0,943)$, seperti pada tabel 1 . Pada tabel 1 didapatkan stroke iskemik dengan kadar Idl normal terbanyak yaitu ada $10(47,6 \%)$, kadar Idl sedang $2(28,6 \%)$, kadar Idl berat $6(50 \%)$, sedangkan untuk stroke hemoragik kadar Idl normal terbanyak $11(52,4 \%)$, kadar Idl sedang $5(71,4 \%)$, dan kadar Idl berat 6 (50\%).

\section{PEMBAHASAN}

Dari hasil penelitian yang dilaksanakan di Rumah Sakit Umum Haji Medan pada tanggal 1 Januari - 30 Maret 2019 diperoleh hasil yaitu, Distribusi pasien stroke berdasarkan usia yang terbanyak kelompok usia 56-62 dengan jumlah 14 pasien (35,0\%),medium usia 63-69 dengan jumlah 11 pasien (27,5\%), usia 70-76 dengan jumlah 7 pasien $(17,5 \%)$, usia 49-55 dengan jumlah 4 pasien $(10,0 \%)$, usia 35-41 dengan jumlah 3 pasien $(7,5 \%)$ usia paling sedikit 77-83 dengan jumlah 1 pasien $(2,5 \%)$, dan tidak ada pasien yang menderita stroke pada usia 42-48.

Distribusi pasien stroke berdasarkan jenis kelamin terbanyak di derita oleh perempuan yaitu 25 orang pasien $(62,5 \%)$, sedangkan pasien laki-laki sebanyak 15 orang pasien $(37,5 \%)$. Berdasakan tabel 4.3 didapatkan hasil bahwa pasien stroke dengan kadar Idl terbanyak adalah kadar Idl normal $(<130 \mathrm{mg} / \mathrm{dl})$ yaitu sebanyak 21 orang $(52,5 \%)$, kadar Idl sedang $(130-159 \mathrm{mg} / \mathrm{dl})$ sebanyak 7 orang $(17,5 \%)$, sedangkan kadar Idl yang tinggi (>160 mg/dl) sebanyak 12 orang (30\%). Berdasarkan tabel 4.4 didapatkan hasil bahwa pasien yang mengalami stroke iskemik ada 20 orang pasien $(50 \%)$, dan pasien stroke hemoragik 20 orang pasien (50\%).

Pada analisa bivariat tidak didapatkan adanya hubungan signifikan antara stroke dengan peningkatan kadar Idl dengan nila $p=0.524$, yang tertera pada tabel 1 yaitu, stroke iskemik dengan kadar Idl normal $10(47,6 \%)$, kadar Idl sedang 3 (42,9\%), kadar Idl berat 7 (58,3\%), sedangkan untuk stroke hemoragik kadar Idl normal 11(52,4\%), kadar Idl sedang 4 $(57,1 \%)$,dan kadar Idl berat $5(41,7 \%)$. 


\begin{tabular}{|c|c|c}
\hline JURNAL PENELITIAN KESMASY & VOL. 1 NO. 2 & $\begin{array}{c}\text { EDITION: NOVEMBER 2018 - } \\
\text { APRIL 2019 }\end{array}$ \\
\hline & http://ejournal.delihusada.ac.id/index.php/JPKSY & \\
\cline { 2 - 3 } RECEIVED: 24 FEBRUARI 2019 & REVISED: 21 MARET 2019 & ACCEPTED: 28 APRIL 2019 \\
\hline
\end{tabular}

Penelitian ini sejalan dengan penelitian yang dilakukan oleh azwita juga menemukan korelasi negative antara stroke dengan kadar Idl kolesterol $(p=0,343)$. Selain itu dijumpai angka kematian dalam 30 hari yang lebih besar pada subyek dengan kadar Idl $<130$ $\mathrm{mg} / \mathrm{dl}$ di banding dengan subjek dengan kadar Idl $>130 \mathrm{mg} / \mathrm{dl}$, hasil ini menunjukan adanya kontribusi kadar Idl dalam meningkatkan keluaran fungsional pada subjek stroke.

Penelitian mengenai kadar LDL kolesterol dengan pasien stroke juga dilakukan oleh astrid laulodkk di RSUP Prof. Dr. R. D. Kandou Manado, di dapatkan hasil Kadar Kolesterol Total, Kolesterol HDL, kolesterol LDL dan Trigliserida pada penelitian ini masih lebih banyak dalam batas normal atau yang diinginkan. Profil lipid abnormal lebih banyak dijumpai pada stroke iskemik dari pada stroke hemoragik.

Penelitian ini juga sejalan dengan penelitian yang dilaksanakan oleh linda soebroto di RUMAH SAKIT Dr. MOEWARDI SURAKARTA, didapatkan hasil X2 hitung $=0,271$. Angka yang didapatkan ini lebih kecil dari harga kritis untuk taraf signifikasi $a=0,05$ yaitu sebesar $X 2=3,841$. Dan dari hasil perhitungan didapatkan Odds Ratio $=1,312$ yang berarti bahwa penderita yang mempunyai kadar LDL tinggi lebih beresiko menderita stroke non hemoragik 1,312 lebih besar daripada penderita yang mempunyai kadar LDL rendah. Berdasarkan hasil perhitungan di atas dapat disimpulkan bahwa secara statistik tidak terdapat hubungan antara kadar LDL dengan penderita stroke non hemoragik.

\section{KESIMPULAN}

Berdasarkan data dan hasil yang didapatkan dari penelitian tentang Hubungan Peningkatan Kadar LDL Kolesterol dengan Pasien Stroke di Rumah Sakit Haji Medan Tahun 2019, dapat ditarik kesimpulan sebagai berikut:

1. Pada penelitian didapatkan hasil bahwa pasien yang terbanyak mengalami stroke hemoragik 20 orang pasien (55\%), yang paling sedikit yaitu stroke iskemik ada 18 orang pasien (45\%).

2. Pada penelitian Hubungan antara stoke dengan peningkatan kadar Idl kolesteol di dapatkan hasil bahwa stroke iskemik dengan kadar Idl normal terbanyak yaitu ada $10(47,6 \%)$, kadar Idl sedang 2 $(28,6 \%)$, kadar Idl berat 6 (50\%), sedangkan untuk stroke hemoragik kadar Idl normal terbanyak $11(52,4 \%)$, kadar Idl sedang $5(71,4 \%)$,dan kadar Idl berat 6 (50\%).

Tidak ditemukan tidak adanya hubungan peningkatankadar Idlkolesterol dengan pasien stoke iskemik di umahsakit haji medan tahun 2016. Dari hasiluji statistic di dapatkan hasil penolakan hipotesis.

\section{KETERBATASAN PENELITIAN}

Pada penelitian ini terdapat kelemahan yang menjadi keterbatasan penelitian ini. Keterbatasan ini berasal dari peneliti sendiri maupun keterbatasan instrumen yang ada yaitu keterbatasan waktu penelitian dan sampel yang terlalu sedikit.

\section{DAFTAR PUSTAKA}

Junaidi, Iskandar 2011, Stroke Akut, Stroke Waspadai Ancamannya. Yogyakarta: Penerbit Andi

Laulo Astrid, dkk, Bahasan, Gambaran Profil Lipid Pada Pasien Stroke Iskemik Dan Stroke Hemoragik yang di Rawat Inap di Irina F RSUP Prof. Dr. R. D. Kandou Manado periode Juli 2015-Juni 2016, Jurnal e-Clinic (eCI), Vol. 4 (2)

Effrina Azwita, et.al. 2015. Hubungan Kadar LDL dengan Kematian dalam 30 hari, Hubungan Kadar Low-Density Lipoprotein Cholesterol dengan Kejadian dan Keparahan Stroke Akut, Neurona Vol. 32 (3)

Zai Joni Trysman Jaya. 2015. Pembahasan, Gambaran Faktor Resiko dan Tipe pada Pasien Stroke di Ruang Rawat Inap RSUD DR. PIRNGADI Medan

Tanto, Chris, 2014. Stroke, Kapita Selekta Kedokteran, ed 4, Media Aesculapius, Jakarta.

Riset Kesehatan Dasar, 2013.

Dewanto, et.al. 2009. Stroke/gangguan Peredaran Darah Otak, Panduan Praktis Diagnosis dan Tatalaksana Penyakit Saraf, ed I, Buku Kedokteran EGC 


\begin{tabular}{|c|c|c|}
\hline JURNAL PENELITIAN KESMASY & VOL. 1 NO. 2 & $\begin{array}{c}\text { EDITION: NOVEMBER } 2018- \\
\text { APRIL } 2019\end{array}$ \\
\hline & http://ejournal.delihusada.ac.id/index.php/JPKSY & \\
\hline RECEIVED: 24 FEBRUARI 2019 & REVISED: 21 MARET 2019 & ACCEPTED: 28 APRIL 2019 \\
\hline
\end{tabular}

Alwiyah Sayyidatu. 2012. Low Density Protein (LDL), Perbedaan Kadar Low Density Lipoprotein (LDL) Darah Tikus Wistar (Rattusnorvegicus) Jantan Setelah Dipapar Stesor Rasa Sakit Rejatan Listrik.

Agusti Nur Islah, et.al. 2012. Proporsi pasien stroke berdasarkan kadar kolesterol LDL, Pofil Rasio Kolesterol LDL dan HDL pada pasien Stroke di bagian saraf RSUD Arifin Achmad Provinsi Riau Periode Januari sampai Desember 2012.

Alchuriyah Siti, dan Chatarina Umbul Wahjuni. 2016. Pendahuluan, Faktor Resiko Kejadian Stroke Usia Muda Pada Pasien Rumah Sakit Brawijaya Surabaya.

Syafrita Yuliarni. 2015. Hasil, Hubungan UsiaPenderita Stroke Iskemik dengan Kadar Beta-amyloid Plasma, CDK-233/ vol. 42 (10)

Suiroka Ip. 2012. Penyakit Degeneratif, Nuha Medika, Yogyakarta

Sastroasmoro, et.al. 2014. Dasar- dasar Metodologi Penelitian Klinis, ed 5, Sagung Setyo.

Notoadmodjo Soekidjo. 2012. Metodologi Penelitian Kesehatan, Jakarta: Rineka Cipta. 